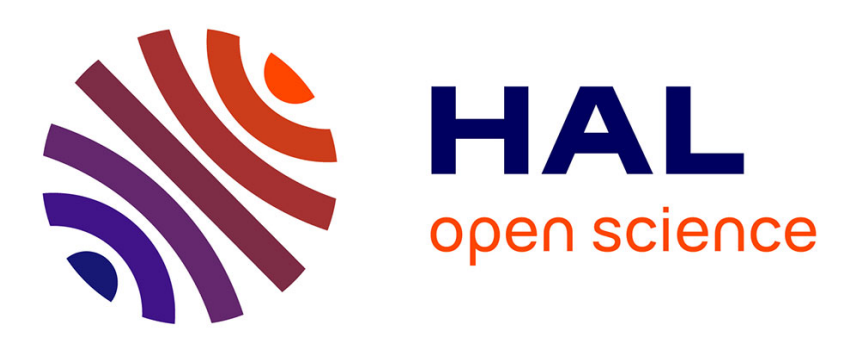

\title{
Modulation of helicobacter pylori transcriptional profile by subinhibitory concentrations of rifampicin
}

K. Momynaliev, V. Chelysheva, O. Selezneva, A. Larin, T. Akopian, D. Alexeev, Véronique Le Berre, Serguei Sokol, Jean Marie François, V. Govorun

\section{- To cite this version:}

K. Momynaliev, V. Chelysheva, O. Selezneva, A. Larin, T. Akopian, et al.. Modulation of helicobacter pylori transcriptional profile by subinhibitory concentrations of rifampicin. Biotechnology. Theory and practice., 2013, pp.23 - 29. 10.11134/btp.2.2013.4 . hal-01849414

\section{HAL Id: hal-01849414 \\ https://hal.science/hal-01849414}

Submitted on 5 Jun 2019

HAL is a multi-disciplinary open access archive for the deposit and dissemination of scientific research documents, whether they are published or not. The documents may come from teaching and research institutions in France or abroad, or from public or private research centers.
L'archive ouverte pluridisciplinaire HAL, est destinée au dépôt et à la diffusion de documents scientifiques de niveau recherche, publiés ou non, émanant des établissements d'enseignement et de recherche français ou étrangers, des laboratoires publics ou privés. 


\title{
Modulation of Helicobacter pylori transcriptional profile by subinhibitory concentrations of rifampicin
}

Print

Details

Hits: 1783

\section{MODULATION OF HELICOBACTER PYLORI TRANSCRIPTIONAL PROFILE BY SUBINHIBITORY CONCENTRATIONS OF RIFAMPICIN}

\author{
Kuvat Momynaliev ${ }^{1}$, Vera Chelysheva ${ }^{2}$, Oksana Selezneva ${ }^{2}$, Andrey Larin ${ }^{2}$, Tatyana Akopian ${ }^{2}$, Dmitry \\ Alexeev $^{2}$, Veronique Le Berre ${ }^{3}$, Serguei Sokol ${ }^{3}$, Jean-Marie Francois ${ }^{3}$, Vadim Govorun ${ }^{2}$ \\ ${ }^{1}$ National Center for Biotechnology, Sh. Valikhanov str. 13/1, Astana, Kazakhstan \\ ${ }^{2}$ Research Institute for Physico-Chemical Medicine, Malaya Pirogovskaya 1A, Moscow, Russia \\ ${ }^{3}$ Biochips platform of Genopole, University of Toulouse, INSA, UPS, INP \& INRA, 135, Avenue de Rangeuil, F-31077, \\ Toulouse
}

momynaliev@biocenter.kz

\begin{abstract}
Subinhibitory concentrations (sub - MICs) of antibiotics do not kill bacteria, but they are able to interfere with important aspects of bacterial cell function, such as adhesion to host cells, surface bacterial energy, susceptibility to host defense mechanisms, inhibition of enzyme function and toxin production. In order to understand how $\mathrm{H}$. pylori copes with environmental stress and what facilitates the emergence of RIF mutants in $\mathrm{H}$. pylori, we used DNA microarrays to compare the gene expression profiles of $H$. pylori in the presence and absence of subinhibitory concentrations of rifampicin (1/16 MIC $(0.1 \mathrm{mg} / \mathrm{L}), 1 / 8 \mathrm{MIC}(0,2 \mathrm{mg} / \mathrm{L}), 1 / 4 \mathrm{MIC}(0,4 \mathrm{mg} / \mathrm{L})$, and $1 / 2 \mathrm{MIC}(0,8 \mathrm{mg} / \mathrm{L})$. We found that ehe expression of 57 genes (of the 1,576 genes analyzed) was increased more than $\geq 1,5$ - fold, and the expression of only 29 genes was decreased more than $\leq 1,5$-fold in significant way ( $p$-value $<0,05$ ), when $H$. pylori was treated with sub-MICs of RIF. No correlation was found between the sub-MICs of RIF and gene expression. We conclude that the alteration in the transcriptional pattern of $H$. pylori after the exposure to sub-MICs of RIF is mainly due to a direct interaction between rifampicin and the RNA polymerase $\beta$-subunit. Finally, we propose that subinhibitory concentrations of rifampicin may lead to an increase in the number of hypermutable cells in the H. pylori population.
\end{abstract}

Keywords: Helicobacter pylori, selection, microarray, rpoB.

\section{INTRODUCTION}

In bacterial populations, an increased mutational frequency under conditions of environmental stress may confer a selective advantage. The presence of antibiotics, even at low concentrations, may constitute an environmental stress. Subinhibitory concentrations (sub-MICs) of antibiotics do not kill bacteria, but they are able to interfere with important aspects of bacterial cell function, such as adhesion to host cells, surface bacterial energy, susceptibility to host defense mechanisms, inhibition of enzyme function and toxin production (reviewed in 10). An increase in the mutation frequency has been observed in different bacterial populations after exposure to sub - MIC antibiotics [13, 16, 30]. For 
S. pneumonia, subinhibitory levels of ciprofloxacin and streptomycin increase the frequency of acquiring rifampicin resistance between 2-and 5-fold, which is comparable to the increase seen in mismatch repair mutants of this species [16]. When $M$. fortuitum is exposed to $1 / 2$ MIC of ciprofloxacin, its mutation rate increases by 72 - to 120 -fold during a selection with quinolones or other antimycobacterial antibiotics [13]. Smaller but significant increases in the mutation rate were also seen when the microorganism was exposed to lower concentrations of ciprofloxacin $(1 / 4 \mathrm{MIC}$ and $1 / 8$ $\mathrm{MIC})$.

The stress response mechanisms that cause an increase in mutation frequency have been widely studied. Antibiotic treatments induce the SOS response, which upregulates multiple genes involved in DNA repair, recombination, mutation, and other functions $[8,9,17,21]$. The SOS response is controlled by LexA, a transcriptional repressor. DNA damage triggers LexA autocleavage, which derepresses the SOS genes controlled by LexA. Once activated, the SOS response promotes the increase in mutational frequency largely through the induction of error-prone DNA polymerases $[2,17]$. Recent studies have shown that the activation of error-prone polymerases occurs at the end of stationary phase and during starvation [18].

The same stress response mechanisms that allow E.coli to adapt to a broad range of stressful conditions are not present in some bacteria from other taxa. Unlike many other bacterial organisms, H. pylori does not have a LexA ortholog [1, 24]; it also lacks many genes involved in DNA repair, recombination, and mutagenesis, such as the mutHL genes (methyl-directed mismatch repair), the umuCD genes (UV-induced mutagenesis), and the SOS-controlled error-prone DNA polymerases. These observations suggest that $H$. pylori may not have a typical SOS response. Nonetheless, $\sim 1 / 4$ of the $\mathrm{H}$. pylori strains isolated from dyspeptic patients show higher mutation frequencies to rifampicin (RIF) resistance than Enterobacteriaceae mismatch-repair defective mutants [5]. The exposure of $H$. pylori to sub-MICs of RIF can help us to understand how H. pylori copes with environmental stress and what facilitates the emergence of RIF mutants in H. pylori.

Here, we examined the gene expression profiles of $H$. pylori in response to treatments with different sub-MICs of RIF. Multiple concentrations of antibiotics were applied to examine dose-specific effects.

\section{MATERIALS AND METHODS}

H. pylori strains and growth medium. H. pylori reference strain 26695 was routinely maintained on Columbia agar (bioMerieux, France) plates supplemented with 10\% heat-inactivated Horse Serum (PAA Lab., Austria), 5\% yeast extract (Russia), and H. pylori-selective antibiotic mix Dent (Oxoid). Liquid culture was grown in BHI broth (3,7\% brain heart infusion (bioMerieux, France) with 10\% inactivated Fetal Bovine Serum (HyClone, USA) and 5\% yeast extract). Both plates and broth cultures were incubated at $37^{\circ}$ under an atmosphere enriched with $5 \% \mathrm{CO}_{2}$ for $2-3$ days.

$D N A$ extraction and sequencing of rpoB. Fresh cultures (middle log phase) of $H$. pylori were suspended in BHI broth ( $10^{5}$ cells $/ \mathrm{ml}$ ) with $10 \%$ inactivated Fetal Bovine Serum, to which RIF had been added at concentrations equivalent to $1 / 16 \mathrm{MIC}(0,1 \mathrm{mg} / \mathrm{L}), 1 / 8 \mathrm{MIC}(0,2 \mathrm{mg} / \mathrm{L}), 1 / 4 \mathrm{MIC}(0,4 \mathrm{mg} / \mathrm{L})$, and $1 / 2 \mathrm{MIC}(0,8 \mathrm{mg} / \mathrm{L})$ and were incubated at $37^{\circ}$ under an atmosphere enriched with $5 \% \mathrm{CO}_{2}$ for 24 hour. Then, chromosomal DNA from wild and sub-MIC treated $H$. pylori strains was isolated with Wizard Genomic DNA Purification (Promega). The PCR reactions were performed under the following conditions: $94^{\circ} \mathrm{C} 3 \mathrm{~min}$, followed by 30 cycles of $94^{\circ} \mathrm{C} 10 \mathrm{~s}, 55^{\circ} \mathrm{C} 10 \mathrm{~s}, 72^{\circ} \mathrm{C} 30 \mathrm{~s}$, with a final elongation at $72^{\circ} \mathrm{C}$ for 5 min. DNA sequencing was carried out on an ABI Prism 3100 Genetic Analyzer (Applied Biosystems) using ABI Prism BigDye Terminator v3.0 Ready Reaction Cycle Sequencing Kit according to the manufacturer's recommendations; sequencing was done in both directions using the same primers as those used for amplification (Table 1).

Table 1. PCR primers for sequencing 


\begin{tabular}{|l|l|c|l|l|}
\hline Primers & Sequence $\left(5^{\prime} \rightarrow 3^{\prime}\right)$ & Gene region & Fragment size & Position and direction \\
\hline $\begin{array}{l}\text { rpoB1 } \\
\text { rpoB2 }\end{array}$ & $\begin{array}{l}\text { ttgattcgctcatgccccat } \\
\text { cacaacctttttataaggggc }\end{array}$ & Cluster I + cluster II & $335 \mathrm{bp}$ & $\begin{array}{l}\text { bp 1492, sense } \\
\text { bp 1827, antisense }\end{array}$ \\
\hline $\begin{array}{l}\text { rpoB149f } \\
\text { rpoB149r }\end{array}$ & $\begin{array}{l}\text { gatccctttgatgacagaacgc } \\
\text { tccctaccataacaggctcagc }\end{array}$ & V149 & $532 \mathrm{bp}$ & $\begin{array}{l}\text { bp 387, sense } \\
\text { bp 919, antisense }\end{array}$ \\
\hline $\begin{array}{l}\text { rpoB2f } \\
\text { rpoB701r }\end{array}$ & $\begin{array}{l}\text { gccccttataaaaaggttgtg } \\
\text { gcgcacattttccctaacg }\end{array}$ & R701 & $626 \mathrm{bp}$ & $\begin{array}{l}\text { bp 1807, sense } \\
\text { bp 2433, antisense }\end{array}$ \\
\hline
\end{tabular}

RNA isolation. Total RNA from $H$. pylori strains incubated at different sub - MICs of RIF was extracted using a commercial RNAqueous-4PCR purification kit (Ambion, USA). The quantity and the quality of the extracted RNA were checked by microcapillary electrophoresis using a Bioanalyzer 2100 (Agilent Technologies, Wilmington, DE, 4 USA). Microarray analysis. The primer set for PCR was purchased from Eurogentec. A total of 3242 primers were designed and synthesized to amplify complete ORFs in the H. pylori genome of strain 26695 . The primers were designed to amplify each ORF beginning at the start codon and ending at the stop codon. The PCR reactions were performed in 96-well plates in a $100 \mu \mathrm{l}$ reaction volume in an MJ Research (Cambridge, MA) PTC-225 DNA Engine Tetrad thermal cycler; the following conditions were used: $94^{\circ} \mathrm{C} 5 \mathrm{~min}$; followed by 30 rounds of 30 seconds at $94^{\circ} \mathrm{C}, 30$ seconds at $50^{\circ} \mathrm{C}$, and $4 \mathrm{~min}$ at $72^{\circ} \mathrm{C}$; followed by one round of $10 \mathrm{~min}$ at $72^{\circ} \mathrm{C}$. To assay the yield and specificity of the amplified ORFs, all PCR reactions were analyzed by electrophoresis on a $1 \%$ agarose gel. The PCR products of 1576 ORFs were successfully obtained (97\%).

The DNA chips were manufactured at the Biochip platform of Toulouse - Genopole on UltraGAPS slides (Corning) using PCR products. Fluorescent-labeled cDNA was synthesized from $5 \mu \mathrm{g}$ of total RNA using the ChipShot Direct Labeling System (Promega). Labeled cDNA was purified using the ChipShot Membrane Clean-up Systems (Promega). Hybridization was carried out in an automatic hybridization chamber (Discovery ${ }^{\mathrm{TM}}$, Ventana). Microarrays were prehybridized in a solution of $1 \% \mathrm{BSA}, 2 \times \mathrm{SCC}$, and $0,2 \%$ SDS for $30 \mathrm{~min}$ at $42^{\circ} \mathrm{C}$ followed by the addition of a mixture containing $200 \mu \mathrm{l}$ of ChipHybe ${ }^{\mathrm{TM}}$ (Ventana), $10 \mu \mathrm{l}$ of Cy3-labelled cDNA, and $10 \mu \mathrm{l}$ of Cy5-labelled cDNA. After $14 \mathrm{hr}$ of hybridization at $42^{\circ} \mathrm{C}$, the DNA chips were washed for $5 \mathrm{~min}$ in $2 \times \mathrm{SSC}, 0,1 \%$ SDS at room temperature and 2 times for 2 min each in 0,1 $\times$ SSC buffer at room temperature. The hybridization signal was detected with a GenePix 4000B laser Scanner (Axon Instruments), and the signal quantification was transformed to numerical values using the integrated GenePix software version 3.01. Experiments (from RNA extraction to image analysis) were repeated two times by swapping the fluorescent dyes $\mathrm{CY} 3$ and $\mathrm{CY} 5$ to reduce the number of false positives due to dye effects.

Data acquisition and analysis. All raw data and full details of normalization and statistical regimes performed using Bioplot software developped at platform Biochips and presented at http://biopuce.insa-toulouse.fr/. This software is an online web service available to all users of the Biochips platform. A complete user's guide is available at http://biopuce.insa-toulouse.fr/ExperimentExplorer/doc/BioPlot/. Raw intensities were background-corrected, log transformed, and normalized by the mean log-intensity of all spots. Log-ratios of normalized intensities from duplicate samples were tested for statistical significance using Student's paired bi-tailed $t$-test. To reduce the false discovery rate, we tested only genes with at least a 1,5-fold variation, and the $p$-value threshold in the Student's $t$-test was set at $\leq 0,05$. To determine the degree to which transcription of a particular gene was regulated at a given concentration of RIF, the normalized value from that concentration was divided by the corresponding value from the wild type and converted to $\log _{10}$. Positive and negative values defined, respectively, up and down-regulated genes under the studied conditions.

Real-time QPCR. Real-time PCR was used to verify the data obtained using the arrays. The reverse transcription reaction was carried out as follows. RNA $(1 \mu \mathrm{g})$ was first denatured at $94^{\circ} \mathrm{C}$ for $30 \mathrm{sec}$ in $10 \mu \mathrm{l}$ of a mixture containing 
(besides RNA) four types of NTPs $(0,5 \mathrm{mM}$ each) and $150 \mathrm{pmol}$ of random hexamer primers. For primer annealing, the mixture was incubated on ice for $30 \mathrm{~min}$. Then, $20 \mathrm{U}$ RNase inhibitor (Promega, USA), $200 \mathrm{U}$ MMLV reverse transcriptase (Promega), and buffer for reverse transcription were added, and the resultant mixture was incubated at $37^{\circ} \mathrm{C}$ for $30 \mathrm{~min}$. PCR was carried out in a volume of $50 \mu$ containing $10 \mathrm{pmol}$ of primers (Table 2), SybrGreen $0.003 \%, 25 \mathrm{mM}$ Tris- $\mathrm{HCl}, \mathrm{pH} 8.3,2,5 \mathrm{mM} \mathrm{MgCl} 2,50 \mathrm{mM} \mathrm{KCl}$, a mixture of four types of dNTPs (0.2 mM each), and 2 U Taq-polymerase. Products were amplified and detected using an ABI PRISM 7000 Sequence Detection System (Applied Biosystems, USA) and MicroAmp Optical 96-well reaction plate/optical caps (Applied Biosystems) in the following mode: denaturation at $94^{\circ} \mathrm{C}$ for $2 \mathrm{~min}$, followed by 40 cycles: $93^{\circ} \mathrm{C}$ for $30 \mathrm{sec}, 50^{\circ} \mathrm{C}$ for $30 \mathrm{sec}$, and $72^{\circ} \mathrm{C}$ for $30 \mathrm{sec}$. Amplification results were assessed using the Sequence Detection System software version1,6 (Applied Biosystems).

Table 2. H. pylori genes whose expression is induced or repressed in response to subinhibitory concentrations of rifampicin

\begin{tabular}{|c|c|c|c|c|c|c|c|}
\hline Expression & $\begin{array}{l}\text { Functional Group - Main } \\
\text { category }\end{array}$ & $\begin{array}{l}1 / 16 \\
\text { MIC }\end{array}$ & $\begin{array}{r}1 / 8 \\
\mathrm{MIC}\end{array}$ & $\begin{array}{c}1 / 4 \\
\mathrm{MIC}\end{array}$ & $\begin{array}{r}1 / 2 \\
\mathrm{MIC}\end{array}$ & ORF ID & Gene name \\
\hline Induced & \multirow{3}{*}{$\begin{array}{l}\text { Biosynthesis of cofactors, } \\
\text { prosthetic groups, and carriers }\end{array}$} & 1.10 & 1.45 & 1.60 & 0.83 & HP0034 & aspartate 1-decarboxylase (panD) \\
\hline & & 1.38 & 1.46 & 1.53 & 1.36 & HP0293 & para-aminobenzoate synthetase (pabB) \\
\hline & & 0.73 & 1.17 & 1.14 & 1.57 & HP1036 & $\begin{array}{l}\text { 7. 8-dihydro-6-hydroxymethylpterin- } \\
\text { pyrophosphokinase (folK) }\end{array}$ \\
\hline & \multirow{2}{*}{ Cellular processes } & 0.94 & 1.31 & 1.20 & 1.51 & HP0327 & flagellar protein $\mathrm{G}$ (flaG) \\
\hline & & 0.54 & 1.04 & 1.11 & 1.75 & HP0536 & Cag pathogenicity island protein (cag15) \\
\hline & \multirow{2}{*}{$\begin{array}{l}\text { Central intermediary } \\
\text { metabolism }\end{array}$} & 1.21 & 1.51 & 1.55 & 1.18 & HP0071 & urease accessory protein (urel) \\
\hline & & 1.19 & 1.45 & 1.55 & 1.05 & HP1186 & carbonic anhydrase \\
\hline & \multirow{3}{*}{ DNA metabolism } & 0.93 & 1.18 & 1.24 & 1.68 & HP0091 & type II restriction enzyme R protein ( $h s d R$ ) \\
\hline & & 1.04 & 1.95 & 1.34 & 1.37 & HP0602 & endonuclease III \\
\hline & & 1.10 & 1.36 & 1.53 & 1.08 & HP0925 & recombinational DNA repair protein $(r e c R)$ \\
\hline & Energy metabolism & 1.37 & 1.54 & 1.59 & 1.32 & HP1131 & ATP synthase F1, subunit epsilon (atpC) \\
\hline & \multirow{2}{*}{$\begin{array}{l}\text { Fatty acid and phospholipid } \\
\text { metabolism }\end{array}$} & 1.41 & 2.03 & 1.68 & 1.56 & HP0559 & acyl carrier protein $(a c p P)$ \\
\hline & & 1.36 & 1.46 & 1.53 & 1.14 & HP1016 & $\begin{array}{l}\text { phosphatidylglycerophosphate synthase } \\
\text { (pgsA) }\end{array}$ \\
\hline & \multirow{4}{*}{ Hypothetical } & 1.08 & 1.41 & 1.64 & 1.24 & HP0234 & $\begin{array}{l}\text { conserved hypothetical integral membrane } \\
\text { protein }\end{array}$ \\
\hline & & 1.39 & 1.41 & 1.65 & 1.49 & HP0759 & $\begin{array}{l}\text { conserved hypothetical integral membrane } \\
\text { protein }\end{array}$ \\
\hline & & 1.25 & 1.42 & 1.59 & 1.27 & HP1423 & conserved hypothetical protein \\
\hline & & 0.84 & 1.38 & 1.29 & 1.50 & HP1587 & conserved hypothetical protein \\
\hline & Other Categories & 1.36 & 1.71 & 1.81 & 1.46 & HP1008 & IS200 insertion sequence from SARA17 \\
\hline & $\begin{array}{l}\text { Pyrimidine ribonucleotide } \\
\text { biosynthesis }\end{array}$ & 1.36 & 1.49 & 1.60 & 1.36 & HP0266 & dihydroorotase (pyrC) \\
\hline & \multirow[b]{2}{*}{ Transcription } & 1.01 & 1.24 & 1.30 & 1.56 & HP0662 & ribonuclease III $(r n c)$ \{Escherichia coli\} \\
\hline & & 1.36 & 1.59 & 1.42 & 1.27 & HP1198 & $\begin{array}{l}\text { DNA-directed RNA polymerase. beta } \\
\text { subunit }(r p o B)\end{array}$ \\
\hline
\end{tabular}




\begin{tabular}{|c|c|c|c|c|c|c|}
\hline & Translation & 1.05 & $\mid 1.55$ & 1.81 & $\mid 1.66$ & HP1040ribosomal protein S15 (rps15) \\
\hline & \multirow{2}{*}{ Transport and binding proteins } & 1.10 & 1.53 & 1.36 & 1.08 & HP0888 $\begin{array}{l}\text { iron(III) dicitrate ABC transporter. ATP- } \\
\text { binding protein }(f e c E)\end{array}$ \\
\hline & & 1.32 & 1.59 & 1.54 & 1.37 & HP1169 glutamine ABC transporter. permease \\
\hline Repressed & Amino acid biosynthesis & 0.75 & 0.59 & 0.74 & 0.78 & HP0107cysteine synthetase (cysK) \\
\hline & Fatty acid and phospholipid & 0.86 & 0.86 & 0.78 & 0.61 & HP0499 $\begin{array}{l}\text { phospholipase A1 precursor (DR- } \\
\text { phospholipase A) }\end{array}$ \\
\hline & metabolism & 0.57 & 0.69 & 0.64 & 0.76 & HP0644 ponserved hypothetical integral membrane \\
\hline & $\begin{array}{l}\text { Central intermediary } \\
\text { metabolism }\end{array}$ & 0.82 & 0.83 & 0.88 & 0.59 & HP0047 $\left.\right|_{(\text {hypE })} ^{\text {hydrogenase expression/formation protein }}$ \\
\hline & Hypothetical & 1.13 & 0.76 & 0.90 & 0.65 & HP0035conserved hypothetical protein \\
\hline & Protein fate & 0.56 & 0.56 & 0.61 & 0.34 & HP0011 co-chaperone (groES) \\
\hline & Regulatory functions & 0.99 & 0.94 & 0.99 & 1.53 & HP0166response regulator (ompR) \\
\hline & Translation & 0.95 & 0.93 & 0.79 & 0.61 & HP0827ss-DNA binding protein 12RNP2 precursor \\
\hline & Transport and binding proteins & 0.91 & 0.80 & 0.81 & 0.65 & HP0607acriflavine resistance protein (acrB) \\
\hline & & 0.74 & 0.65 & 0.77 & 0.63 & HP1427 ${ }_{(h p n)}^{\text {histidine-rich, metal binding polypeptide }}$ \\
\hline
\end{tabular}

\section{RESULTS}

To understand the adaptive response of $H$. pylori to sub - MICs of RIF, a DNA microarray technique was used to analyze the transcriptional changes in H. pylori after exposure to different sub - MICs of RIF. It should be noted, that the pre-incubation of $H$. pylori with sub-MICs of RIF does not lead to the emergence of mutations in the rpoB gene that confer resistance.

Microarrays containing 1,576 ORFs of $H$. pylori strain 26695 were hybridized with fluorescently labeled cDNAs synthetised from total RNA extracted from $H$. pylori cultures that had been incubated either in the control condition or in various sub-MICs of RIF. A ratio of intensity of the Cy5 and Cy3 fluorophore at each spot was obtained by scanning with an Axon scanner; this ratio represents the change in total mRNA content after exposure sub-MICs of RIF. To reduce the number of false positive values due to dye effects, experiments (from RNA extraction to image analysis) were repeated two times, swapping the fluorescent dyes Cy3 and Cy5.

The expression of only 57 genes (of the 1,576 genes analyzed) was increased more than $\geq 1.5-$ fold, and the expression of only 29 genes was decreased more than $\leq 1.5$-fold in significant way ( $p$-value $<0,05$ ), when $H$. pylori was treated with sub-MICs of RIF. Hence, the expression of the vast majority of the genes analyzed was not detectable during the exposure to sub-MICs of RIF. The average change in the 57 up-regulated genes and 29 downregulated genes is shown in Tables 2 and 3. The expression level of only gene, HP0412, increased by more than twofold. The expression of the other genes changed by less than twofold. When the 24 up-regulated genes with known function were classified by function, several different types of genes were found and are shown in Table 2. The $r p o B$ gene, encoding the beta subunit of the DNA-directed RNA polymerase, a target of RIF, was one of those identified. Also, genes involved in biosynthesis/ metabolism processes (panD, pabB, folK, atpC, acpP, pgsA, pyrC, HP1186), DNA metabolism ( $h s d R, H P 0602$, recR), transcription/translation ( $r n c, r p s 15)$, transport (fecE, glnP), and cellular processes (flaG, cag15) were upregulated. Genes that were down-regulated upon exposure to sub - MICs of RIF belong to the same functional groups, except for groES, which encodes a co-chaperone (protein fate), and ompR, 
which encodes a response regulator (regulatory functions). Three differentially expressed genes, hypE (HP0047), carbonic anhydrase (HP1186), and urel (HP0071), are pH regulated genes.

To identify patterns of gene expression that are regulated by sub - MICs of RIF, we performed an average-linking hierarchical cluster analysis on those genes whose expression changed by more than 1,5-fold (either up or down). The object of the clustering was to group genes with similarly-regulated expression levels under sub - MICs of RIF (Fig. 1). We found that the genes that respond to sub-MICs of RIF fall into three general categories: those that are down-regulated in the presence sub-MICs of RIF (cluster a, 31 genes), those that show dose-dependent regulation (cluster b, 17 genes), and those that are up-regulated but not dependent on sub-inhibitory concentrations of RIF (cluster c, 38 genes). Cluster $\mathbf{b}$ contains the genes whose expression depends on sub-MICs of RIF. Some of the dose-regulated genes in this group are the flagellar gene, flag (HP0327); the pyrophosphokinase gene, folk (HP1036); the restriction enzyme gene, $h s d R$ (HP0091); the response regulator gene, ompR (HP0166); the pathogenicity gene, cag15 (HP0536); and the ribonuclease gene, rnc (HP1040).

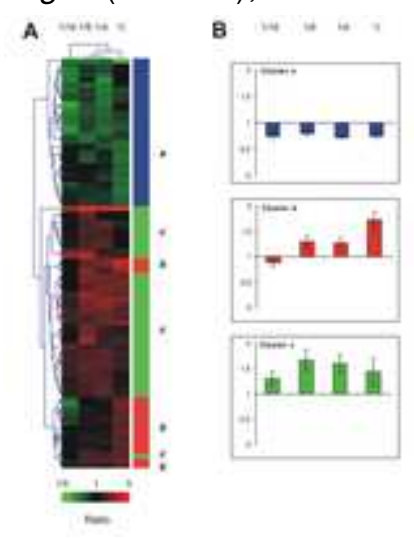

Figure 1. Cluster analysis of gene expression patterns at different sub-MICs of rifampicin (A). Hierarchical clustering was applied to the expression data from a set of 86 (of 1,576 total) genes measured under four sub - MICs of rifampicin: 1/16 MIC, 1/8 MIC, $1 / 4$ MIC, and $1 / 2$ MIC. Transcript levels varied by at least 1.5 -fold relative to the control condition. Data from 16 hybridizations were used. The color scale that was used to represent the expression ratios is shown on the bottom. The colored bars with labels $a$ to $c$ refer to the identified clusters of genes. Cluster a (31 genes): downregulated genes in the presence sub-MICs of RIF; cluster $\mathbf{b}$ : dose-dependent regulated genes (17 genes); and cluster c: up-regulated, but not dependent on subinhibitory concentrations of RIF (38 genes). On the right is shown a profile bar graph for each cluster, in which the mean log ratio of that cluster in each experimental condition is plotted (B)

Figure 1. Cluster analysis of gene expression patterns at different sub-MICs of rifampicin (A). Hierarchical clustering was applied to the expression data from a set of 86 (of 1,576 total) genes measured under four sub - MICs of rifampicin: 1/16 MIC, $1 / 8 \mathrm{MIC}, 1 / 4 \mathrm{MIC}$, and $1 / 2$ MIC. Transcript levels varied by at least 1.5 -fold relative to the control condition. Data from 16 hybridizations were used. The color scale that was used to represent the expression ratios is shown on the bottom. The colored bars with labels $a$ to $c$ refer to the identified clusters of genes. Cluster a (31 genes): down-regulated genes in the presence sub-MICs of RIF; cluster $\mathbf{b}$ : dose-dependent regulated genes (17 genes); and cluster c: up-regulated, but not dependent on sub-inhibitory concentrations of RIF (38 genes). On the right is shown a profile bar graph for each cluster, in which the mean log ratio of that cluster in each experimental condition is plotted (B)

Real-time RT-PCR analysis was used as an independent method to validate the microarray results, since it measures the accumulation of product during the linear phase of the PCR and is an accurate and reproducible approach to gene quantification [25, 26]. We quantified the transcripts of genes involved in biosynthesis/metabolism (panD, pabB, urel, carbonic anhydrase, atpC, acpP, pgsA, pyrC), transcription/translation (rpoB), transport (fecE u $g(n P)$, protein fate (groES), and HP0759, HP1423, and HP1008. The real-time RT-PCR confirmed the up-regulation of panD, pabB, urel, HP1186, atpC, acpP, pgsA, pyrC, rpoB, fecE и gInP, HP0759, HP1423, and HP1008 and the down-regulation of groES (Fig. 2).

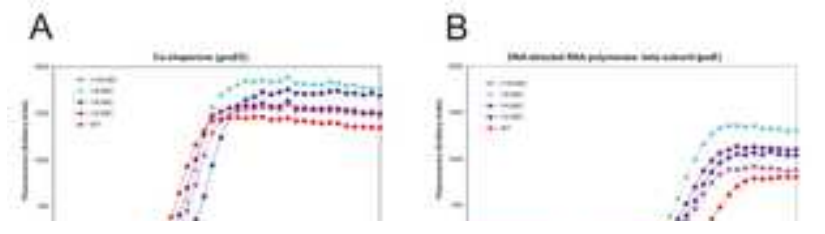

Figure 2. Real-time PCR. The cDNAs encoding the cochaperone (groES) (A), beta subunit of the DNA-directed RNA polymerase $(r p o B)(B)$, urease accessory protein 

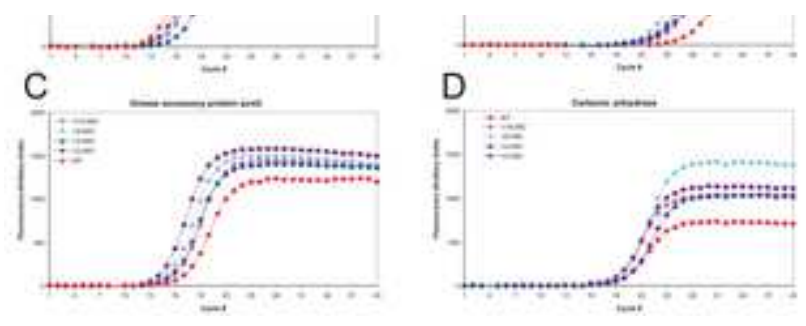

(urel) (C), and periplasmic carbonic anhydrase (D) from typical experiments of the microarray analysis at different subinhibitory concentration of rifampicin were subjected to PCR amplification. The lines represent amplifications from cDNAs generated from the RNAs isolated from $H$. pylori cultures incubated at 1/16 MIC (0,1 mg/L), 1/8 MIC (0,2mg/L), 1/4 MIC (0,4 mg/L), 1/2 MIC (0,8 mg/L), and control conditions.

Figure 2. Real-time PCR. The cDNAs encoding the co-chaperone (groES) (A), beta subunit of the DNA-directed RNA polymerase $(r p o B)(B)$, urease accessory protein (urel) $(C)$, and periplasmic carbonic anhydrase (D) from typical experiments of the microarray analysis at different subinhibitory concentration of rifampicin were subjected to PCR amplification. The lines represent amplifications from cDNAs generated from the RNAs isolated from $H$. pylori cultures incubated at 1/16 MIC (0,1 mg/L), 1/8 MIC (0,2mg/L), 1/4 MIC (0,4 mg/L), 1/2 MIC (0,8 mg/L), and control conditions.

\section{DISCUSSION}

It was shown that rifampicin at subinhibitory concentrations alters the global bacterial transcription patterns [14, 28, 29]. Among the genes affected by antibiotics are those related to bacterial stress responses, as well as genes for accessory functions, such as motility and virulence (reviewed in 6 and 29). Previous work using cDNA-microarrays established a key role for $m f d$ (mutation frequency decline, which encodes a transcription-repair coupling factor involved in DNA repair) in the resistance of Campylobacter pylori (closely related Helicobacter) to fluoroquinolines [15]. The mutation of $m f d$ results in an approximately 100-fold reduction in the rate of spontaneous acquisition of ciprofloxacin resistance, while its overexpression elevates the mutation frequency. This result inspired us to use cDNA-microarrays to define the mechanism by which rifampicin at sub-MICs affects $H$. pylori.

Our analysis of $H$. pylori treated with sub-MICs of RIF allowed us to detect transcriptional variability in 86 of 1576 $(5,4 \%)$ genes (Tables 2,3$)$. We found that the differentially regulated genes can be divided into three clusters: those whose expression is decreases at all sub-MICs of RIF (cluster a, 31 gene), dose-regulated genes that increase their expression with increasing concentration of antibiotic (cluster b, 17 genes), and those whose expression increases in response to antibiotic in a dose-independent fashion (cluster c, 38 genes) (Fig.1). Taking into account the S-shaped dependence of the mutation frequency on concentration, the most interesting genes are those in cluster $\mathbf{b}$, whose expression is dose-dependent. In that cluster, we found genes with known functions: 7,8-dihydro6-hydroxymethylpterin-pyrophosphokinase (folK), cag pathogenicity island protein (cag15), flagellar protein G (flaG), response regulator $(o m p R)$, ribonuclease III $(r n c)$, and type II restriction enzyme R protein $(h s d R)$.

Table 3. $H$. pylori genes of unknown function whose expression is induced or repressed in response at least to one subinhibitory concentrations of rifampicin

\begin{tabular}{|c|c|c|c|c|c|}
\hline Expression & $1 / 16 \mathrm{MIC}$ & $1 / 8 \mathrm{MIC}$ & $1 / 4 \mathrm{MIC}$ & $1 / 2 \mathrm{MIC}$ & ORF ID \\
\hline Induced & 0.98 & 1.65 & 1.74 & 2.50 & HP0016 \\
\hline & 1.02 & 1.76 & 1.71 & 1.54 & HP0057 \\
\hline & 1.14 & 1.75 & 1.38 & 1.24 & HP0058 \\
\hline & 1.04 & 1.44 & 1.33 & 1.50 & HP0081 \\
\hline & 1.19 & 1.44 & 1.55 & 0.97 & HP0085 \\
\hline & 1.01 & 1.53 & 1.77 & 2.45 & HP0129 \\
\hline & 0.68 & 1.23 & 1.11 & 1.57 & HP0167 \\
\hline
\end{tabular}




\begin{tabular}{|l|l|l|l|l|l|} 
& 0.67 & 0.65 & 0.59 & 0.93 & HP0847 \\
\hline & 0.55 & 0.92 & 0.50 & 1.02 & HP0984 \\
\hline & 0.72 & 0.81 & 0.60 & 0.75 & HP1223 \\
\hline & 0.51 & 0.71 & 0.60 & 0.78 & HP1326 \\
\hline
\end{tabular}

Of the genes whose expression is altered by sub-MICs of RIF, we found ompR (regulatory functions) and $r n c$ (transcription) to be the most interesting. The rnc gene is interesting due to its role in RNA proccessing. Another gene, whose expression is modulated by sub-MICs of RIF, ompR (HP0166), is a part of the HP0165-HP0166 twocomponent system, which directly controls the transcription of genes that are involved in cellular $\mathrm{pH}$ homeostasis. Of the genes that are under the control of the response regulator HP0166, we found urel (HP0071), rnc (HP0662,) fecE (HP0888), carbonic anhydrase (HP1186), and genes coding for proteins with unknown function (HP1396, HP0667, HP0673, HP0674) [27]. Carbonic anhydrase (HP1186) is an important periplasmic protein that catalyzes the conversion of $\mathrm{CO}_{2}$, produced by urease, to $\mathrm{HCO}_{3}{ }^{-}[19]$. The protein encoded by the urel gene, Urel, is a proton-gated urea entry channel that allows for the buffering of the periplasm of the organism with urease activity, which is essential for survival and growth in an acidic medium $[22,26]$ as well as for the colonization of mouse and gerbil stomachs $[20$, 23].

Another differentially expressed gene, hypE (HP0047), may also take part in cellular pH homeostasis, though it is not regulated by HP0166. The protein HypE (or HupE) is required for the expression of a catalytically active hydrogenase in many systems. The hydrogenase enzyme catalyses the redox equilibrium of $2 \mathrm{H}^{+}+2 \mathrm{e}^{-} \leftrightarrow \mathrm{H}_{2}$. It is interesting that the expression of HP0011 decreases with the addition of sub - MICs; this gene, codes for two proteins: heat shock protein $\mathrm{HspA}$, which is needed for complete urease activity, and $\mathrm{Hpn}$, which deposits $\mathrm{Ni}^{2+}$ metal from the center of active urease [11, 12]. The fact that the expression of genes involved in the maintenance of $\mathrm{pH}$-homeostasis and regulated by HP0166 changes with sub - MICs perhaps indicates that the intracellular pH changes upon the addition of antibiotic.

The gene for the response regulator HP0166 has been shown to be essential for H. pylori cell growth, while the cognate histidine kinase HP0165 is not essential under in vitro culture conditions [3]. This result suggests that the HP0165-independent response regulator HP0166 is necessary for the transcription of target genes that are essential for in vitro growth, while an additional set of genes is activated or repressed under environmental conditions that trigger the histidine kinase activity of the sensor protein, HP0165. Hence, it is highly probable that the activation of HP0166 and functionally associated proteins in $\mathrm{H}$. pylori indicates the switching on of other pH-independent mechanisms in response to the addition of sub-MICs of rifampicin. For instance, according to Beletskii (4), the frequency of induced mutations depends on level of transcription of the target cell and the physiologic state of cell. As shown above, a preincubation of $H$. pylori with sub-MICs of RIF causes an increase in RpoB expression; thus, it is no surprise that the frequency of mutations in all samples increases in comparison to the control. Obviously, the mutability of the microorganism depends on the functional activity of its mismatch repair system. In our study, we found that doses of rifampicin that are sub - MIC induce the synthesis of endonuclease III (HP0602), which protects the cell from the toxic and mutagenic action of alkylating agents.

Taking into account the fact that we failed to identify a direct correlation between sub - MICs of RIF and gene expression, it may be that the genes that are regulated by sub - MICs of RIF include not only stress-related genes that allow $H$. pylori to adapt to RIF but also genes that alter transcription through a direct interaction of rifampicin with the RNA polymerase $\beta$-subunit. It was shown in $S$. typhimurium and E. coli that subinhibitory concentrations of rifampicin can modulate (activate or repress) the transcription of a significant proportion of genes $(5 \%)$ [14, 28], as detected by bacterial promoter-reporter constructs. It should be noted that the expression of $m f d$ (HP1541), which plays a key role in the development of fluoroquinolone resistance in $C$. jejuni, does not change in $H$. pylori after exposure to sub - 
MICs of RIF. Thus, the mechanism by which the frequency of mutations increases during a selection with sub - MICs of RIF in $\mathrm{H}$. pylori remains unclear. Considering that, in clinical isolates of $\mathrm{H}$. pylori, hypermutable strains are often found [5], we suppose that, along with the modulation of gene expression, a selection of cells with a hypermutable phenotype simultaneously takes place.

\section{ЛИТЕРАТУРА}

1. Alm R.A., Ling L.S., Moir D.T., King B.L., Brown E.D., Doig P.C., Smith D.R., Noonan B., Guild B.C., deJonge B.L., Carmel G., Tummino P.J., Caruso A., Uria-Nickelsen M., Mills D.M., Ives C., Gibson R., Merberg D., Mills S.D., Jiang Q., Taylor D.E., Vovis G.F., Trust T.J. 1999. Genomic-sequence comparison of two unrelated isolates of the human gastric pathogen Helicobacter pylori. Nature. - 397: 176-180.

2. Beaber J.W., Hochhut B., Waldor M.K. 2004. SOS response promotes horizontal dissemination of antibiotic resistance genes. Nature. - 427: 72-74.

3. Beier D., Frank R. 2000. Molecular characterization of two-component systems of Helicobacter pylori. J. Bacteriol. - 182: 2068-2076.

4. Beletskii A., Bhagwat A.S. 1996. Transcription-induced mutations: increase in C to T mutations in the nontranscribed strand during transcription in Escherichia coli. Proc Natl Acad Sci USA. - 93: 13919-13924.

5. Björkholm B., Sjölund M., Falk P.G., Berg O.G., Engstrand L., Andersson D.I. 2001. Mutation frequency and biological cost of antibiotic resistance in Helicobacter pylori. Proc Natl Acad Sci USA. - 98: 14607-12.

6. Brazas M.D., Hancock R.E. 2005. Using microarray gene signatures to elucidate mechanisms of antibiotic action and resistance. Drug Discov. Today 10:1245-1252.

7. Campbell E.A., Korzheva N., Mustaev A., Murakami K., Nair S., Goldfarb A., Darst S.A. 2001. Structural mechanism for rifampicin inhibition of bacterial RNA polymerase. Cell. - 104: 901-912.

8. Cirz R.T., Jones M.B., Gingles N.A., Minogue T.D., Jarrahi B., Peterson S.N., Romesberg F.E. 2007. Complete and SOS-mediated response of Staphylococcus aureus to the antibiotic ciprofloxacin. J Bacteriol. - 189: 531-539.

9. Cirz R.T., O'Neill B.M., Hammond J.A., Head S.R., Romesberg F.E. 2006. Defining the Pseudomonas aeruginosa SOS response and its role in the global response to the antibiotic ciprofloxacin. J Bacteriol. - 188: 7101-7110.

10. Davies J., Spiegelman G.B., Yim G. 2006. The world of subinhibitory antibiotic concentrations.Curr Opin Microbiol. - 9: 445-453.

11. Ge R., Watt R.M., Sun X., Tanner J.A., He Q.Y., Huang J.D., Sun H. 2006. Expression and characterization of a histidine-rich protein, Hpn: potential for Ni2+ storage in Helicobacter pylori. Biochem J. - 393: 285-293.

12. Gilbert J.V., Ramakrishna J., Sunderman F.W. Jr., Wright A., Plaut A.G. 1995. Protein Hpn: cloning and characterization of a histidine-rich metal-binding polypeptide in Helicobacter pylori and Helicobacter mustelae. Infect Immun. - 63: 2682-2688.

13. Gillespie S.H., Basu S., Dickens A.L., O'Sullivan D.M., McHugh T.D. 2005. Effect of subinhibitory concentrations of ciprofloxacin on Mycobacterium fortuitum mutation rates. J Antimicrob Chemother. - 56: 344-348.

14. Goh E.B., Yim G., Tsui W., McClure J., Surette M.G., Davies J. 2002. Transcriptional modulation of bacterial gene expression by subinhibitory concentrations of antibiotics. Proc. Natl. Acad. Sci. USA. - 99:17025-17030.

15. Han J., Sahin O., Barton Y.W., Zhang Q. 2008. Key role of Mfd in the development of fluoroquinolone resistance in Campylobacter jejuni. PLoS Pathog. - 4: e1000083.

16. Henderson-Begg S.K., Livermore D.M., Hall L.M. 2006. Effect of subinhibitory concentrations of antibiotics on 
mutation frequency in Streptococcus pneumoniae.J Antimicrob Chemother. - 57: 849-854.

17. Kelley W.L. 2006. Lex marks the spot: the virulent side of SOS and a closer look at the LexA regulon. Mol Microbiol. - 62: 1228-1238.

18. Layton J.C., Foster P.L. 2003. Error-prone DNA polymerase IV is controlled by the stress-response sigma factor, RpoS, in Escherichia coli. Mol Microbiol. - 50: 549-561.

19. Marcus E.A., Moshfegh A.P., Sachs G., Scott D.R. 2005. The periplasmic-carbonic anhydrase activity of Helicobacter pylori is essential for acid acclimation. J. Bacteriol. - 187: 729-738.

20. Mollenhauer-Rektorschek M., Hanauer G., Sachs G., Melchers K. 2002. Expression of Urel is required for intragastric transit and colonization of gerbil gastric mucosa by Helicobacter pylori. Res. Microbiol. - 153: 659-666.

21. Power E.G., Phillips I. 1992. Induction of the SOS gene (umuC) by 4-quinolone antibacterial drugs. J Med Microbiol. - 36: 78-82.

22. Scott D.R., Marcus E.A., Weeks D.L., Lee A., Melchers K., Sachs G. 2000. Expression of the Helicobacter pylori urel gene is required for acidic pH activation of cytoplasmic urease. Infect. Immun. - 68: 470-477.

23. Skouloubris S., Thiberge J.M., Labigne A., De Reuse H. 1998. The Helicobacter pylori Urel protein is not involved in urease activity but is essential for bacterial survival in vivo. Infect. Immun. - 66: 4517-4521.

24. Tomb J.F., White O., Kerlavage A.R., Clayton R.A., Sutton G.G., Fleischmann R.D., Ketchum K.A., Klenk H.P., Gill S., Dougherty B.A., Nelson K., Quackenbush J., Zhou L., Kirkness E.F., Peterson S., Loftus B., Richardson D., Dodson R., Khalak H.G., Glodek A., McKenney K., Fitzegerald L.M., Lee N., Adams M.D., Hickey E.K., Berg D.E., Gocayne J.D., Utterback T.R., Peterson J.D., Kelley J.M., Cotton M.D., Weidman J.M., Fujii C., Bowman C., Watthey L., Wallin E., Hayes W.S., Borodovsky M., Karp P.D., Smith H.O., Fraser C.M., and Venter J.C. 1997. The complete genome sequence of the gastric pathogen Helicobacter pylori. Nature. - 388:539-47.

25. Wang G., Wilson T.J., Jiang Q., Taylor D.E. 2001. Spontaneous mutations that confer antibiotic resistance in Helicobacter pylori. Antimicrob Agents Chemother. - 45: 727-733.

26. Weeks D.L., Eskandari S., Scott D.R., Sachs G. 2000. A H + -gated urea channel: the link between Helicobacter pylori urease and gastric colonization. Science. - 287: 482-485.

27. Wen Y., Feng J., Scott D.R., Marcus E.A., Sachs G.J. 2006. Involvement of the HP0165-HP0166 two-component system in expression of some acidic-pH-upregulated genes of Helicobacter pylori. Bacteriol. - 188:1750-1761.

28. Yim G., de la Cruz F., Spiegelman G.B., Davies J. 2006. Transcription modulation of Salmonella enterica serovar Typhimurium promoters by sub-MIC levels of rifampin. J Bacteriol. - 188: 7988-7991.

29. Yim G., Wang H.H., Davies J. 2006. The truth about antibiotics. Int. J. Med. Microbiol. 296:163-170.

30. Ysern P., Clerch B., Castańo M., Gibert I., Barbé J., Llagostera M. 1990. Induction of SOS genes in Escherichia coli and mutagenesis in Salmonella typhimurium by fluoroquinolones. Mutagenesis. - 5: 63-6.

\section{PEЗЮME}

Субингибирующие концентрации (суб-МИК) антибиотиков не оказывают бактерицидного действия на бактерии, но они могут оказывать влияние на важные аспекты бактериальной клеточной функции, такие как адгезия к клеткам-хозяевам, восприимчивость к защитным механизмам хозяина, ингибировать ферменты и влиять на выработку токсинов и т.п. Для того, чтобы понять, как H. pylori справляется с внешним стрессом и что способствует появлению рифампицин-устойчивых мутантов РИФ, мы использовали ДНК-микрочипы для сравнения профилей экспрессии генов $H$. pylori в присутствии и отсутствии субингибирующей концентрации рифрампицина (1/16 МИК (0,1 мг/Л), 1/8 МИК (0,2 мг/Л), 1/4 МИК (0,4 мг/Л) и 1⁄2 MІС (0,8 мг/Л)). Было найдено, что экспрессия 57 генов (из 1576 проанализированных генов) увеличилась более чем $\geq 1,5$ раза, а экспрессия 29 
генов была достоверно снижена более чем $\leq 1,5$ раза $(\mathrm{p}<0,05)$, когда $H$. pylori инкубировали в присутствии субингибирующих концентраций рифампицина (РИФ). Однако, не было обнаружено никакой дозозависимой корреляции между суб-МИК РИФ и экспрессией генов. Мы пришли к выводу, что изменения транскрипционных профилей H. pylori после воздействия суб-МИК РИФ происходит в основном за счет прямого взаимодействия рифрампицина и $\beta$-субъединицы РНК-полимеразы. Полагаем, что субингибирующие концентрации рифрампицина могут быть причиной увеличения количества гипермутабельных клеток в H. pylori популяции.

Ключевые слова: Helicobacter pylori, отбор, микроэррей, rроB.

\section{TYЙIH}

Антибиотиктердің субингибициялаушы шоғырланулары (суб-МИК) бактерияларға бактерицидті әрекет жасамайды, бірақ олар иелік етуші жасушаларға жабысып қалу, иенің қорғаныш тетіктеріне қабылдағыштық, фрерменттерді тежеу және уыт өндіруге әсер ету және тағы сол сияқты бактериялық жасушалық функцияның маңызды аспектілеріне әсерін тигізуі мүмкін.Н. Pylori сыртқы күйзелісті қалай жеңетінін және рифампицинге тұрақты РИФ мутанттарының пайда болуына мүмкіндік туғызатынын түсіну үшін, біз рифампицинсубингибициялаушы шоғырлануының қатысуымен және оның жоғында H. Pylori тектері дәлдігінің профильдерін салыстыру үшін ДНК-микрочиптерді пайдаландық (1/16 МИК (0,1мг/Л), 1/8 МИК (0,2 мг/Л), 1/4 МИК $(0,4 \mathrm{Mr} /$ Л) и 1/2 MIC (0,8 мг/Л)). Н. Pylori-ді рифрампицинніңсубингибициялаушы шоғырлануларының қатысуымен инкубациялағанда (РИФ)57 тектің дәлдігі (1576 анализден өткен тектерден) $\geq 1,5$ еседен астам артқандығы, ал 29 тектің дәлдігі $\leq 1,5$ еседен астам $(p<0,05)$ анық кемігендігітабылды. Алайда суб-МИК РИФ және тектер дәлдігі арасында ешқандай дозалық тәуелді корреляция байқалған жоқ. Біз суб-МИк РИФ әсерінен кейін H. Pylori-дің транскрипциялық профильдерінің өзгеруі негізінен рифампициннің және $\beta$-суббірлігі РНК-полимеразасының тікелей өзара іс-әрекеті есебінен жүреді деген қорытындыға келдік. Біз рифрампицинніңсубингибициялаушы шоғырланулары. H. Pylori популяциясында гипермутабельді жасушалар санының көбею себебі болуы мүмкін деп ойлаймыз.

Кілтті сөздер: Helicobacter pylori, іріктеу, микроэррей, гроВ. 